\title{
EVALUATION OF SEDIMENT PRODUCTION AND SILTATION IN A SMALL EARTH DAM IN FERNANDÓPOLIS, SP
}

\section{LUIZ S. VANZELA ${ }^{1}$, DIEGO L. G. GRECCO², JOSÉ N. DA COSTA NETO ${ }^{3}$, GILMAR O. SANTOS}

\begin{abstract}
The siltation is a natural process, but can be accelerated by human actions and results in major problems for the reservoirs, reducing its useful volume for irrigation. An example of this problem was the reduction of the area of mirror water of Fernandópolis municipal dam in $48.3 \%$ during 20 years. Therefore, this study aimed to evaluate the production of sediments and siltation of Fernandópolis municipal dam from a methodology that can be applied to small earth dams for agricultural purposes. For this, it was monitored, monthly throughout the year, the volume of sediment deposited in the reservoir. The percentage of retention sediment in Fernandópolis municipal dam ranged from 53.9 to $94.5 \%$, that associated with a high specific sediment yield, will cause its full silting in at most 57 years. It is recommended to minimize this process the restoration of permanent preservation areas and the removal of $17,500 \mathrm{~m}^{3}$ of sediment from the riverbed of the dam.
\end{abstract}

KEYWORDS: hydro-sedimentology, use and land occupation, erosion.

\section{AVALIAÇÃO DA PRODUÇÃO DE SEDIMENTOS E DO ASSOREAMENTO EM PEQUENA BARRAGEM DE TERRA DE FERNANDÓPOLIS-SP ${ }^{1}$}

RESUMO: O assoreamento é um processo natural, mas que pode ser potencializado pelas ações antrópicas e resulta em grandes problemas para os reservatórios, reduzindo seu volume útil para a irrigação. Um exemplo deste problema foi a redução da área do espelho d'água da represa municipal de Fernandópolis em 48,3\%, durante 20 anos. Por isso, este trabalho teve como objetivo avaliar a produção de sedimentos e o assoreamento da represa municipal de Fernandópolis a partir de metodologia que pode ser aplicável a pequenas barragens de terra para fins agrícolas. Para isto, foi monitorado, mensalmente, durante um ano, o volume de sedimento depositado na represa. $\mathrm{O}$ percentual de retenção de sedimentos na represa municipal de Fernandópolis variou de 53,9 a $94,5 \%$, que associada a uma alta produção específica de sedimentos, provocará seu completo assoreamento em, no máximo, 57 anos. Recomendam-se para minimizar este processo, a restauração das áreas de preservação permanente e a retirada de $17.500 \mathrm{~m}^{3}$ de sedimentos do leito da represa.

PALAVRAS-CHAVE: hidrossedimentologia, uso e ocupação do solo, erosão.

\section{INTRODUCTION}

Siltation is the deposition of sediment transported by water courses, due to the reduction of the kinetic energy at levels below that needed to keep them in suspension. This dynamic is defined by the saturation value (CARVALHO, 2008) which depends on the flow rate and slope of the water courses, in addition to particle size and specific weight of the sediment. This is a process that occurs naturally, but when potentiate due to inadequate soil management can result in degradation of quality and availability of the water (POLETO et al., 2010).

\footnotetext{
${ }^{1}$ Eng $^{\mathrm{o}}$ Agrônomo, Prof. Doutor, Departamento de Agronomia, UNICASTELO/Fernandópolis - SP, Fone: (17) 3465-4200, lsvanzela@yahoo.com.br.

${ }^{2}$ Eng $^{\mathrm{o}}$ Ambiental e Sanitarista, FIFE/Fernandópolis - SP, grecco.amb@gmail.com.

${ }^{3}$ Eng $^{\mathbf{o}}$ Ambiental e Sanitarista, FIFE/Fernandópolis - SPF, jniloneto@ gmail.com.

${ }^{4}$ Doutorando em Agronomia, Departamento de Engenharia Agrícola, UNESP/Jaboticabal, gilmar_engambiental@yahoo.com.br Recebido pelo Conselho Editorial em: 9-10-2013

Aprovado pelo Conselho Editorial em: 28-4-2014
}

Eng. Agríc., Jaboticabal, v.34, n.5, p. 912-924, set./out. 2014 
The change of soil use, with agriculture and urban perimeters associated with the average slope in the basins, contribute to increased soil loss and sediment concentration in water (VANZELA et al., 2010; MINGOTI \& VETTORAZZI, 2011) aggravating the process of siltation. This occurs because the reduction in infiltration rate of the soil leads to increasing the surface runoff (GOMES et al., 2007) and, consequently, the kinetic energy of the water, maximizing the capacity to carry sediment.

According to OLIVEIRA et al. (2011) the devastation of vegetation surrounding the rivers brings serious implications to the natural environment, such as siltation, pollution and contamination by products of agricultural origin. Effects such as these are obtained by WU et al. (2012), which quantify the anthropogenic and climatic impacts on sediment production, it was observed that in the 1980s, even with the construction of dams; the deforestation induced an increase of almost $20 \%$ in the sediment load of the Pearl River (Zhujiang), China.

Among the main impacts caused by anthropogenic soil use on the watershed are those referring to the reduction of the useful life of the busbars. These hydraulic structures are artificial artworks that alter the flow regime, increasing their susceptibility to silting process. Reducing the velocity of water flow due to the enlargement of the cross section (ALBERTIN et al., 2010; SANTOS \& HERNANDEZ 2013) creates favorable conditions for sedimentation of solid material carried by the water course or arising by runoff from the watershed. This behavior, however, is responsible for the significant reduction in sediment load in rivers that have dams (SYVITSKI \& KETTNER, 2011). The temporal variation of sediment production in watersheds in the short term is also related to rainfall patterns, as observed by SILVA JUNIOR et al. (2011).

The reservoirs also called dikes are of utmost importance to regional development and management of water resources, as among their main use in the current situation, can be highlight: hydroelectricity, irrigation, urban water supply and drought control (UNITED NATIONS ENVIRONMENTAL PROGRAMME, 2007). Therefore, the reduced supply of water due to silting in the reservoirs can have negative consequences for regional development, especially in cities that depend on these structures for irrigation.

The city of Fernandópolis located northwest of the state of São Paulo, has a reservoir used for landscaping purposes, which showed a reduction of $48.3 \%$ in its water mirror in 1979-2008 (VANZELA, 2012), mainly due to the urban evolution associated with agricultural occupation in its drainage basin. Therefore, it is essential to analyze the magnitude of the process as the basis for the adoption of preventive or corrective measures. In this context, this study aimed to evaluate the production of sediments and siltation in small dam in Fernandópolis, SP.

\section{DESCRIPTION OF THE SUBJECT}

\section{Location}

This study was conducted at the Municipal Dam in Fernandópolis - SP, which drains a basin of 549.38 ha, located in the urban area of the municipality, between latitudes $20^{\circ} 15^{\prime} 43$ "and $20^{\circ} 15^{\prime} 53^{\prime \prime}$ South and longitude 50 $14^{\prime} 19$ "and 50¹4'06" West (Figure 1). 


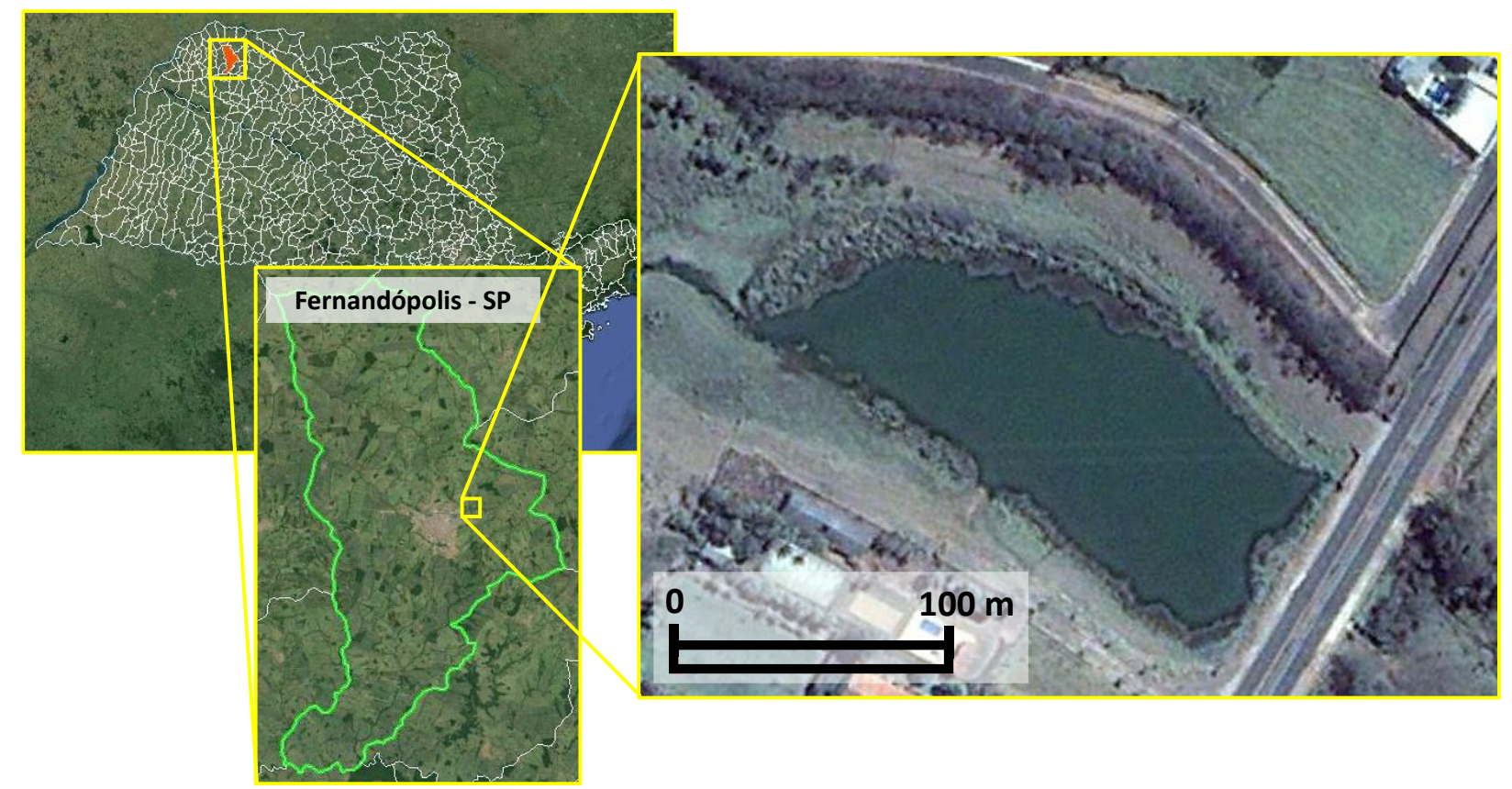

FIGURE 1. Location of Fernandópolis Municipal Dam - SP.

\section{Characteristics of Drainage Basin and Climate}

By Köppen classification, the climate is Aw, Tropical Wet (ROLIM et al., 2007), with dry and mild winter and hot and rainy summer with an average annual temperature of $23.5{ }^{\circ} \mathrm{C}$ and average rainfall of $1,321 \mathrm{~mm} \mathrm{yr}^{-1}$. The soil of the basin that drains water to the dam, the object of study, is from the PVA1 group that is Clayey Red-Yellow soil (OLIVEIRA et al., 1999) and other characteristics are presented in Figure 2.

a

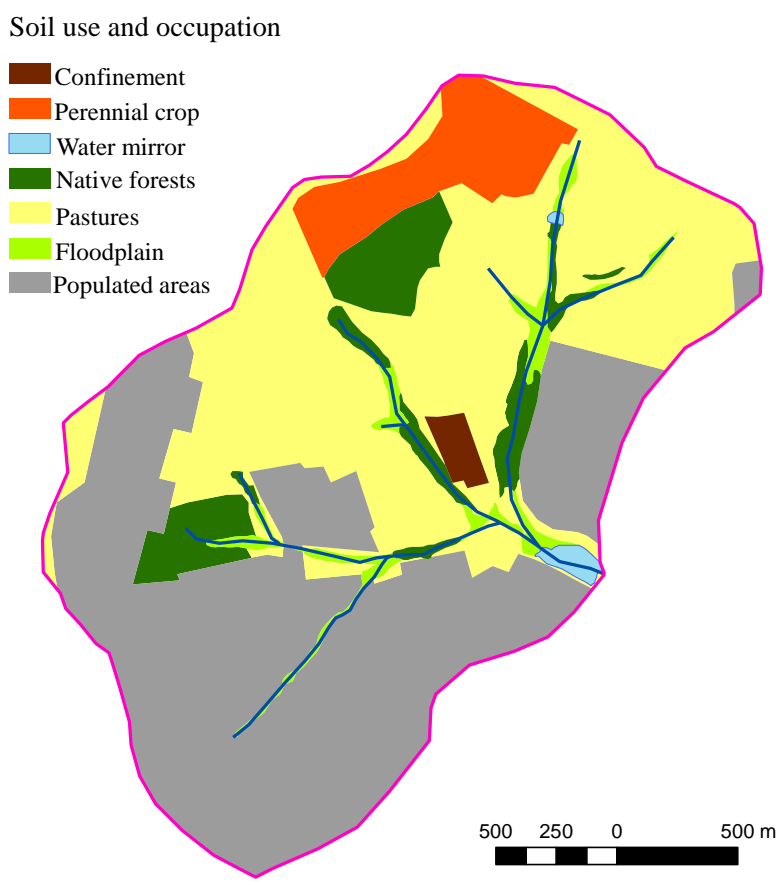

b

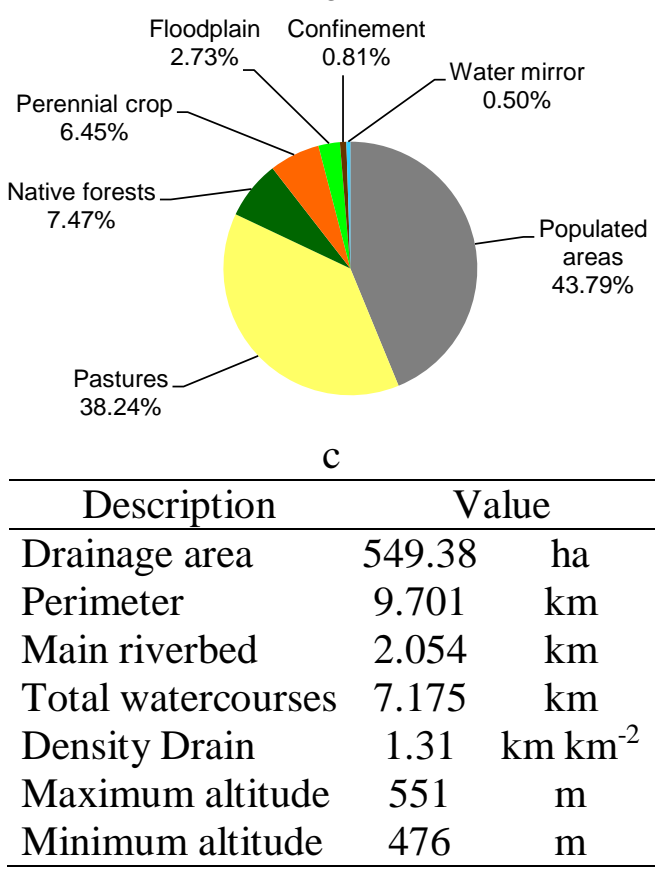

FIGURE 2. Current land use (a, b) and characteristics (c) of the watershed in upstream of the dam studied. 
The study was conducted from February 2011 to February 2012, period in which the total rainfall was $1,373 \mathrm{~mm}$ and total potential evapotranspiration was 1,426 mm (INTEGRATED CENTER OF AGRO METEOROLOGICAL INFORMATION, 2012) (Figure 3).

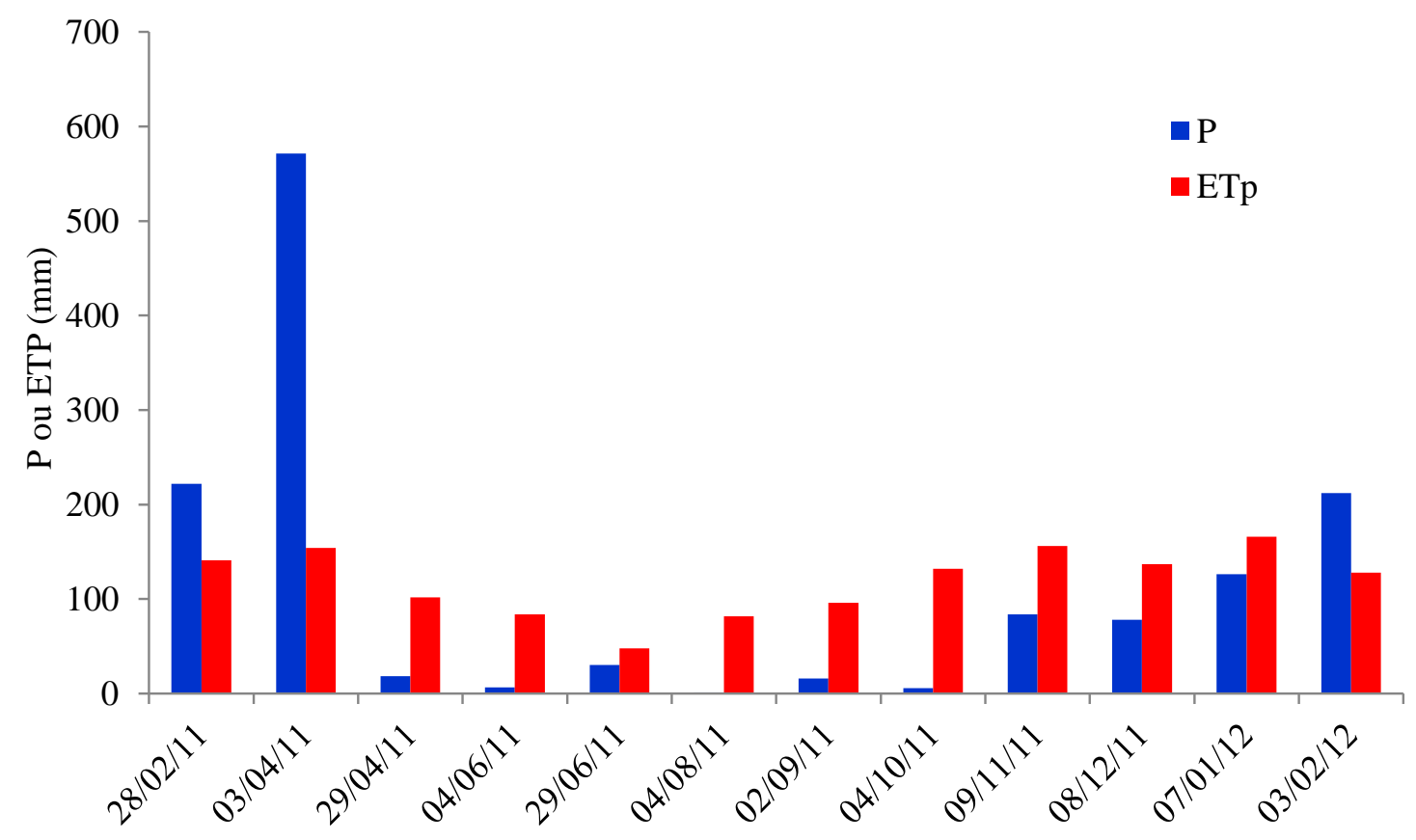

FIGURE 3. Precipitation Totals (P) and evapotranspiration (ETP) during the research period.

\section{Methodology}

Analysis of siltation of the dam was based on equation 1 (CARVALHO et al., 2000.)

$$
\mathrm{T}=\frac{\mathrm{V}_{\mathrm{res}}}{365 \cdot \mathrm{S}}
$$

where,

$\mathrm{T}=$ Time to siltation (years);

$\mathrm{V}_{\text {res }}=$ Total volume of the dam $\left(\mathrm{m}^{3}\right)$, and

$\mathrm{S}=$ Volume of sediment in the dam $\left(\mathrm{m}^{3} \mathrm{~d}^{-1}\right)$.

The total volume of the dam was determined by bathymetric survey conducted in April 2012, using the method vau of bathymetry with a PVC pipe graduated 5 by $5 \mathrm{~cm}$ for the collection of depths and one station, based on two GPS control points deployed near the dam. Data were downloaded in DataGeosis Office software and depths introduced in the planimetric data on spreadsheet software. Then, the digital terrain model (DTM) was generated from an irregular grid of 33 depth points and calculated the area of the water surface and the total volume of the dam resulting in $18,548 \mathrm{~m}^{2}$ and $18,598 \mathrm{~m}^{3}$ respectively (Figure 4). 
a

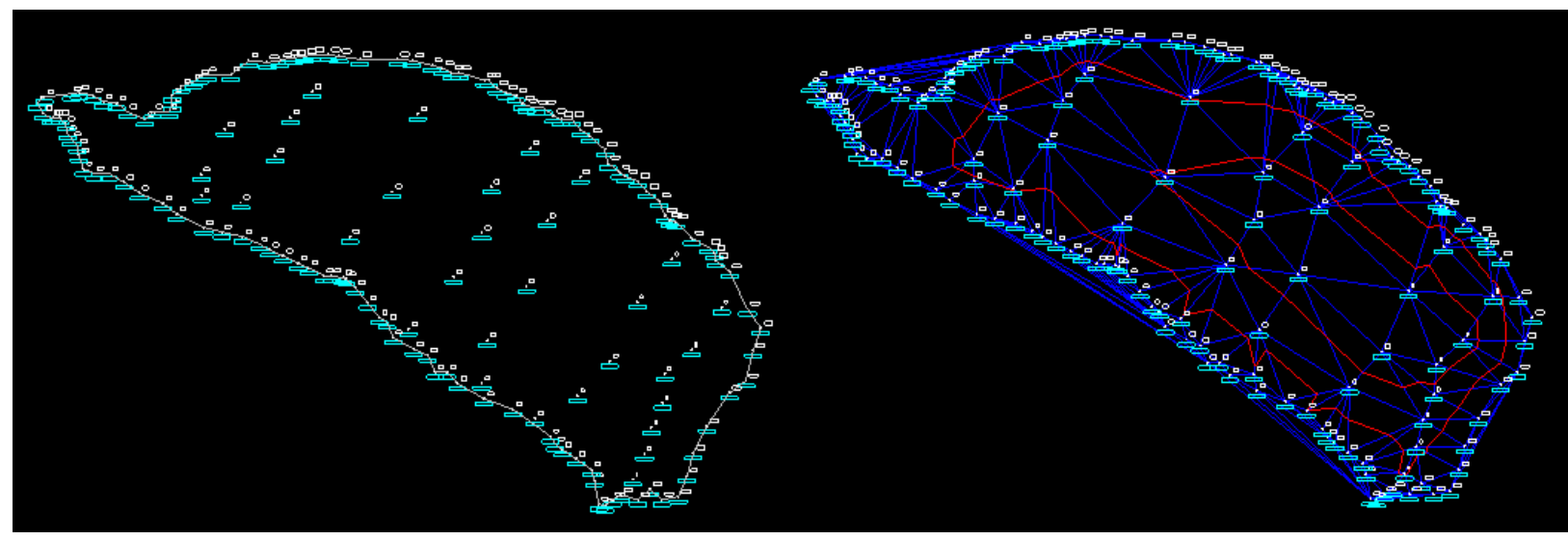

c

d

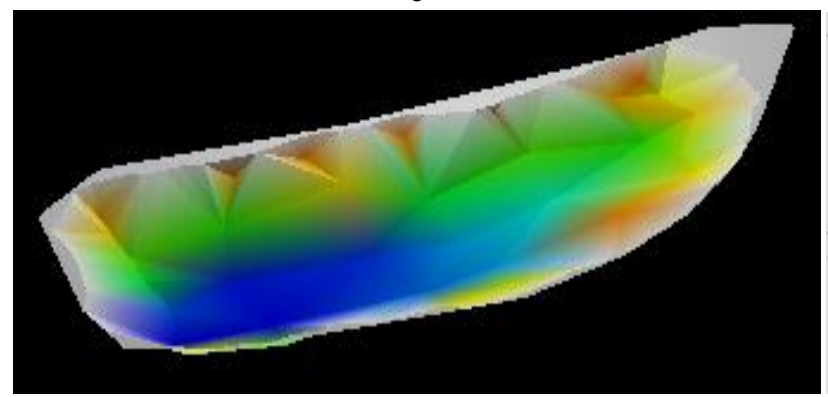

Parameters

Base Surface:

full bathymetry

Surface of Reference:

Plan $(Z=97.65 \mathrm{~m})$

Interval of Integration:

2.00

Results

Clipping Volume:

$0.00 \mathrm{~m}^{3}$

Volume of Landfill:

$18598.46 \mathrm{~m}^{3}$

FIGURE 4. Detail of the points survey in the depth and in the boundary of the dam (a), of the DTM generated (b), 3D model of the depth (c) and the volume calculation by the software (d).

The calculation of the volume of sediment in the dam (S) was performed using Equation 2:

$$
\mathrm{S}=\frac{\mathrm{S}^{\prime}}{\mathrm{d}_{\mathrm{s}}}
$$

where,

$\mathrm{S}$ - Volume of sediment withheld in the dam $\left(\mathrm{m}^{3} \mathrm{~d}^{-1}\right)$;

$\mathrm{S}^{\prime}$ - mass of sediment withheld in the dam $\left(\mathrm{kg} \mathrm{d}^{-1}\right)$, and

$\mathrm{d}_{\mathrm{s}}$ - Density of solid sediments on the bottom of the dam $\left(\mathrm{kg} \mathrm{m}^{-3}\right)$.

To determine the density of solid sediments on the bottom of the dam $\left(\mathrm{d}_{\mathrm{s}}\right)$, on the occasion of the bathymetry, 7 samples were collected of approximately $20 \mathrm{~g}$ with the same tube used to collect the depths of the dam.

Then the samples were placed in plastic containers and brought to the Laboratory of Geology and Soil Physics of the Integrated Colleges of Fernandópolis for analysis. After obtaining the results, it was considered the value of the density of solids, the average of all collected samples, that is, $1.89 \mathrm{~g} \mathrm{~cm}^{-3}\left(1,890 \mathrm{~kg} \mathrm{~m}^{-3}\right)$ (Figure 5). 
a

b
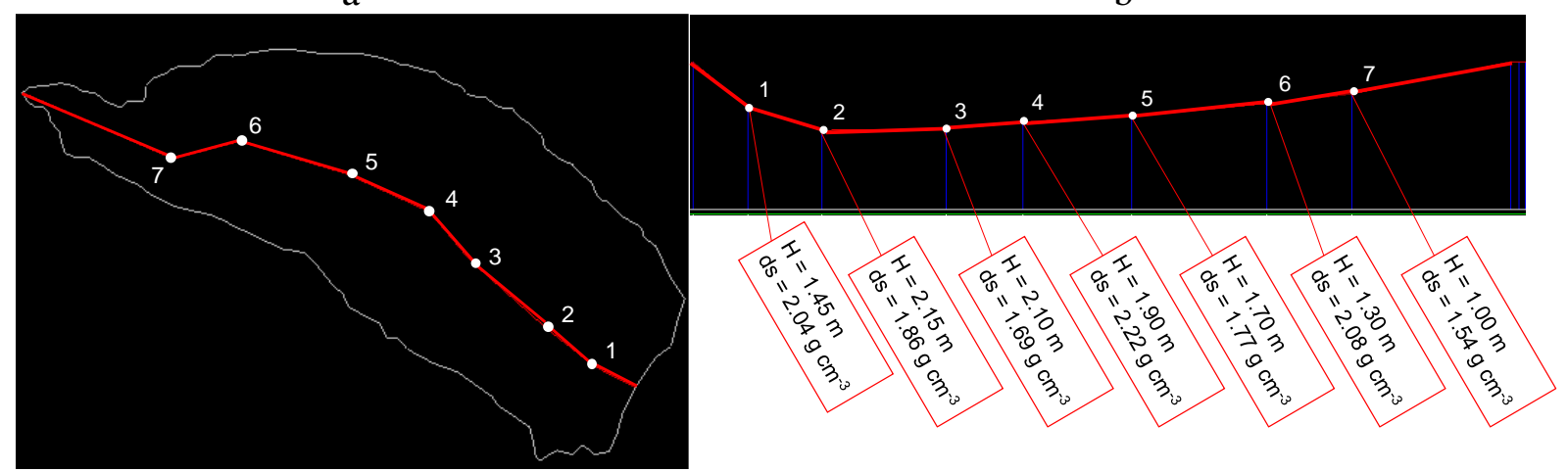

FIGURE 5. Details of sample locations on frontal (a) and profile view (b), with the respective depths $(\mathrm{H})$ and the density particle $\left(\mathrm{d}_{\mathrm{s}}\right)$.

The mass of sediment retained on the dam ( $\left.\mathrm{S}^{\prime}\right)$ was determined with the aid of the equation 3 :

$$
\mathrm{S}^{\prime}=\mathrm{DST}_{\mathrm{e}}-\mathrm{DST}_{\mathrm{s}}
$$

where:

$\mathrm{S}^{\prime}$ - Mass of sediment retained in the dam $\left(\mathrm{kg} \mathrm{d}^{-1}\right)$;

$\mathrm{DST}_{\mathrm{e}}$ - Total sediment discharge entering the dam $\left(\mathrm{kg} \mathrm{d}^{-1}\right)$, and

$\mathrm{DST}_{\mathrm{s}}$ - Total sediment discharge coming out of the dam $(\mathrm{kg})$.

The total solid discharge entering the reservoir was determined by adding the solid discharge at the points $\mathrm{A}, \mathrm{B}$ and $\mathrm{C}$ and total solid discharge coming out of the dam, measured at the exit of the discharger (concrete tube) located at point D (Figure 6).

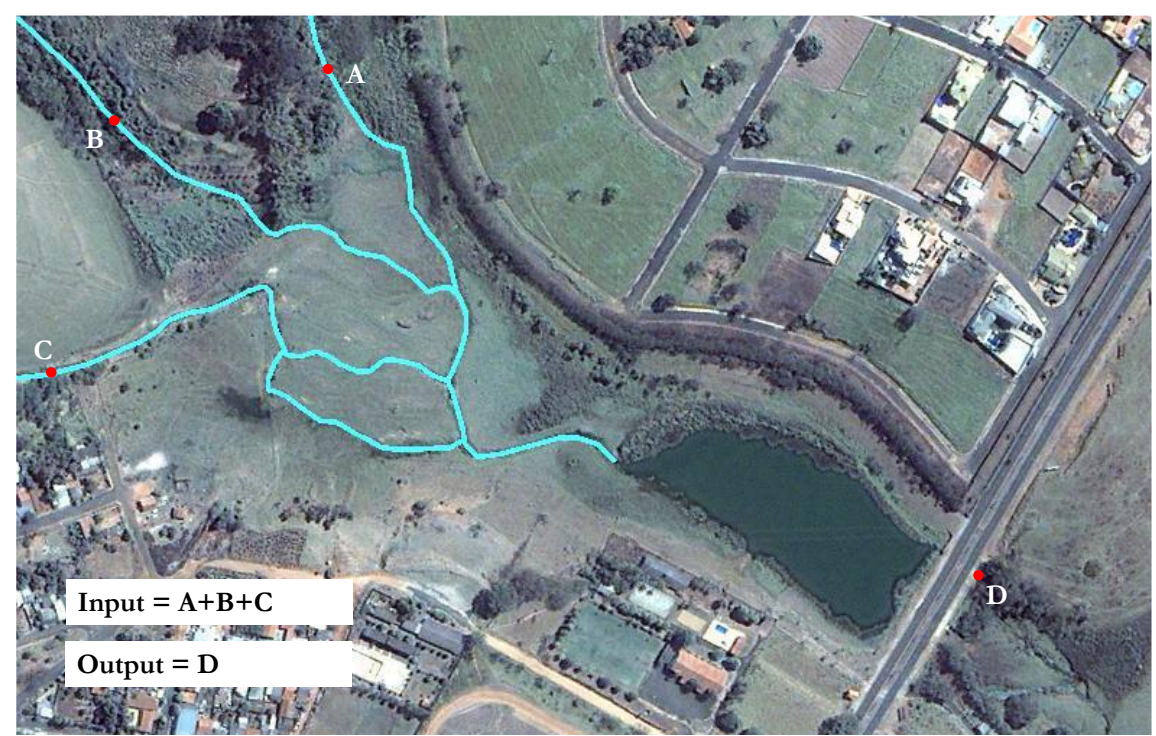

FIGURE 6. Point location of flow measurement and water samples for determination of total solids.

The total solid discharge from each point $\mathrm{A}, \mathrm{B}$ and $\mathrm{C}$ was determined by the equation 4 :

$$
\mathrm{DST}=\mathrm{DSS}+\mathrm{DSL}
$$

where,

DST $=$ Total solid discharge $\left(\mathrm{kg} \mathrm{d}^{-1}\right)$;

DSS $=$ Suspended solid discharge $\left(\mathrm{kg} \mathrm{d}^{-1}\right)$, and 
DSL = Riverbed Solid discharge $\left(\mathrm{kg} \mathrm{d}^{-1}\right)$.

The total solid discharge (DST) coming out of the dam ( point D) was determined only by the suspended solid discharge (DSS), because of the discharger from upstream to downstream of the dam is above the bottom of it.

The suspended solid discharges, of input or output of the dam, were determined according to the equation 5:

$$
\text { DSS }=\left(C_{\mathrm{ST}} \cdot \mathrm{Q}\right) \cdot 0,024
$$

where,

$$
\begin{aligned}
& \text { DSS = Suspended solid discharge }\left(\mathrm{kg} \mathrm{d}^{-1}\right) ; \\
& \text { CST }=\text { Total solids }\left(\mathrm{mg} \mathrm{L}^{-1}\right), \text { and } \\
& \mathrm{Q}=\text { Stream flow }\left(\mathrm{m}^{3} \mathrm{~h}^{-1}\right)
\end{aligned}
$$

Stream flow was determined by the integrating float method. Concentrations of total solids were obtained by gravimetric analysis of water samples, both measured at points A, B, C and D. The water analyzes were realized at the Laboratory of Geology and Soil Physics of the Integrated Colleges in Fernandópolis.

The solid discharge of the riverbed was determined by the method of COLBY (1954) (CARVALHO, 2008) according to the equation 6:

$$
D S L=\left(39 \cdot v_{m}^{3.36} \cdot L \cdot K\right) \cdot 10^{3}
$$

where,

$\mathrm{DSL}=$ Solid discharge on the riverbed $\left(\mathrm{kg} \mathrm{d}^{-1}\right)$;

$\mathrm{V}_{\mathrm{m}}=$ Mean flow velocity $\left(\mathrm{m} \mathrm{s}^{-1}\right)$;

$\mathrm{L}=$ Linear width of the channel section $(\mathrm{m})$, and

$\mathrm{K}=$ Correction factor.

The linear section width of the channel and the average flow velocity were obtained at the time of flow measurements. The correction factor was determined based on the total solids concentration and relative concentration, using the equation 7 :

$$
K=1.18 \cdot\left(\frac{C_{S T}}{C_{R}}\right)^{0.5}
$$

where,

$\mathrm{K}=$ Correction factor;

$\mathrm{C}_{\mathrm{ST}}=$ total solids concentration $\left(\mathrm{mg} \mathrm{L}^{-1}\right)$, and

$\mathrm{C}_{\mathrm{R}}=$ Relative concentration $\left(\mathrm{mg} \mathrm{L}^{-1}\right)$ determined by Colby diagram.

Samples and measurements of stream flow were performed monthly for a period of 1 year, totaling 12 samples of water and stream flow measurements at the entrance and at the exit of the dam.

\section{Result Analysis}

The correlation coefficients ( $r$ ) were determined for all variables with the accumulated precipitation of the 7 days preceding the measurements (P7d) and presented their variability as a 
function of time. The classification of the correlation coefficient ( $r$ ) was the one proposed by Hopkins (2000) (Table 1).

TABLE 1. Classification of correlations in accordance with the correlation coefficient (r).

\begin{tabular}{cc}
\hline Correlation coefficient & Correlation \\
\hline $0.0 \leq \mathrm{r}<0.1$ or $-0.1<\mathrm{r} \leq 0.0$ & Very low \\
$0.1 \leq \mathrm{r}<0.3$ or $-0.3<\mathrm{r} \leq-0.1$ & Low \\
$0.3 \leq \mathrm{r}<0.5$ or $-0.5<\mathrm{r} \leq-0.3$ & Moderate \\
$0.5 \leq \mathrm{r}<0.7$ or $-0.7<\mathrm{r} \leq-0.5$ & High \\
$0.7 \leq \mathrm{r}<0.9$ or $-0.9<\mathrm{r} \leq-0.7$ & Very High \\
$0.9 \leq \mathrm{r}<1.0$ or $-1.0<\mathrm{r} \leq-0.9$ & Extremely high \\
\hline
\end{tabular}

It was performed statistical comparisons between averages, for the values of total solids concentrations, stream flow and total solid discharges of entry and exit from the dam, distributed between the rainy and dry seasons. For this, it was used the criterion of GRAVETTER \& WALLNAU (1995), whose differentiation occurs when there is no overlap of the upper and lower limits of the standard errors of the means.

The rainy and dry periods were considered, respectively, the periods of surplus and water deficit, defined according to the sequential water balance (PEREIRA et al., 2002). The available water capacity (AWC) considered was $100 \mathrm{~mm}$ and rainfall data and potential evapotranspiration data were obtained from automatic station in Fernandópolis (INTEGRATED CENTER OF AGRO METEOROLOGICAL INFORMATION,2012).

The retained volume of sediment and time for siltation were analyzed by the probable variation around the mean using the standard error of the mean for the rainy and dry period. Statistical analyzes were performed with the SPSS software. All calculations, tables and graphs were performed with the aid of Microsoft Excel software.

\section{Concentration of Total Solids}

The values of total solids concentration range from 108 to $701 \mathrm{mg} \mathrm{L}^{-1}$ at the input $\left(\mathrm{CST}_{\mathrm{e}}\right)$ and from 107 to $625 \mathrm{mg} \mathrm{L}^{-1}$ at the output (CSTs) of the dam, with high correlation between $\mathrm{CST}_{\mathrm{e}}$ and the P7d $(r=0.63)$ and moderate correlation between CSTs and the P7d $(r=0.37)$ (Figure 7a). In the rainy periods $\left(577 \pm 83\right.$ and $\left.387 \pm 140 \mathrm{mg} \mathrm{L}^{-1}\right)$ and dried $\left(219 \pm 53\right.$ and $190 \pm 36 \mathrm{mg} \mathrm{L}^{-1}$ ) (Figure 7b) were not obtained significant differences between the means of $\mathrm{CST}_{\mathrm{e}}$ and $\mathrm{CST}_{\mathrm{s}}$. Most significant results were obtained by LU \& SIEW (2006), which showed an average reduction of $40 \%$ in sediment concentration after installation of dams on the Lower Mekong River in China

a

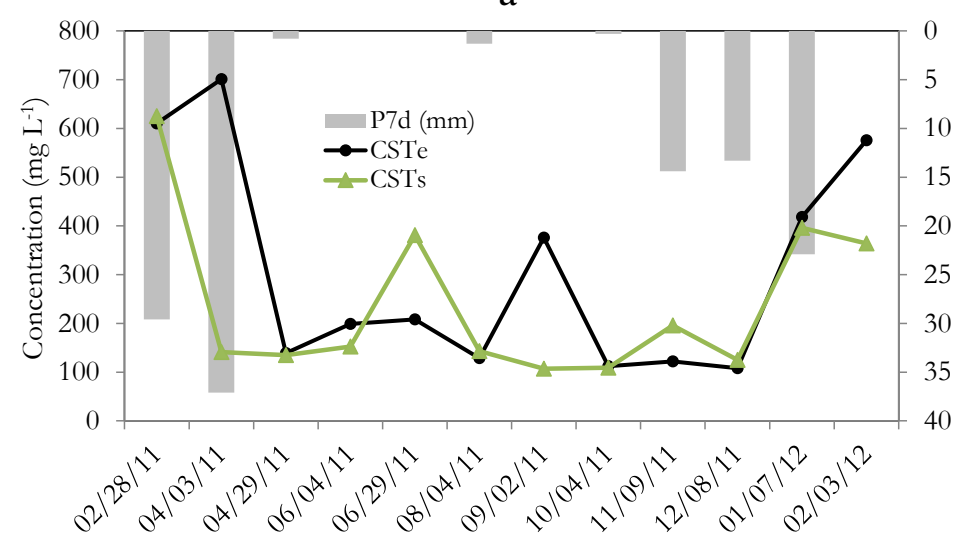

b

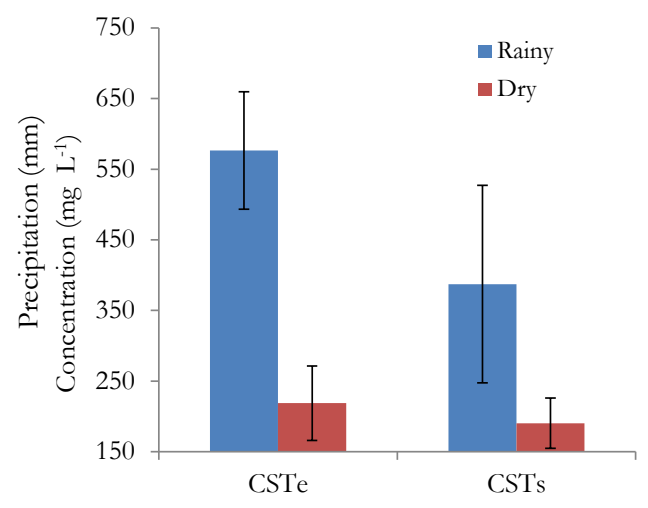

FIGURE 7. Temporal variation of the rainfall during the 7 days before the assessments (P7d) and of the total solids concentrations of the input (CSTe) and output (CSTs) (a) and averages of CSTe and CSTs in the wet and dry periods (b). 
The significant increase in the concentration of total solids in the rainy period, both input and output (Figure 7b), can be explained by the greater potential for entrainment of sediment in the period associated with the degree of urban and agricultural occupation in the area of the drainage basin, correlating positively with the concentration of sediment in water (VANZELA et al., 2010; SILVA et al., 2008). Similar behavior has also been observed in different rivers in Brazil (MELO et al., 2009; MEDEIROS et al., 2011).

Independently of the observed behaviors, it was found that the values for this variable are well above of those found in basins with preserved native vegetation (TUNDISI \& TUNDISI, 2010), indicating great agricultural and urban pressure on water resources in the water basin .

\section{Stream flow}

Stream flow rates ranged from 106.95 to $383.97 \mathrm{~m}^{3} \mathrm{~h}^{-1}$ at the input (Qe) and 39.36 to 277.37 $\mathrm{m}^{3} \mathrm{~h}^{-1}$ at the output (Qs) of the dam, both with high positive correlation $(\mathrm{r}=0.58$ to input and $\mathrm{r}$ $=0.47$ to output) with P7d (Figure 8a). In this case, there were significant differences between the means of both Qe and Qs in the rainy period $\left(248.84 \pm 67.61\right.$ and $\left.115.82 \pm 56.65 \mathrm{~m}^{3} \mathrm{~h}^{-1}\right)$ as the dry $\left(151.79 \pm 14.05\right.$ and $\left.70.41 \pm 9.23 \mathrm{~m}^{3} \mathrm{~h}^{-1}\right)$, that is, the volume damped by the dam ranged on average from 4.8 to $81.3 \%$ in the rainy period and 42.2 to $63.1 \%$ in the dry period (Figure $8 \mathrm{~b}$ ). These damping percentages were similar to those obtained by SOUZA FILHO (2013), who observed in several dams located in the basin of Paraguay, Cuiabá and Taquari rivers, percentage of control of the stream flow varying from 5.9 to $87.9 \%$.

The damping effect of the stream flow can also be verified by the lack of differentiation between the mean of the rainy and dry period at the output of the dam.

a

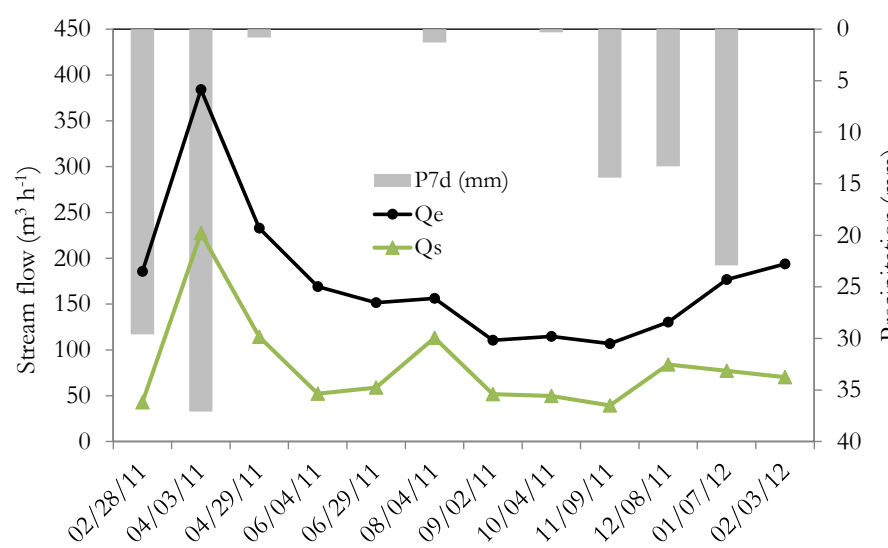

b

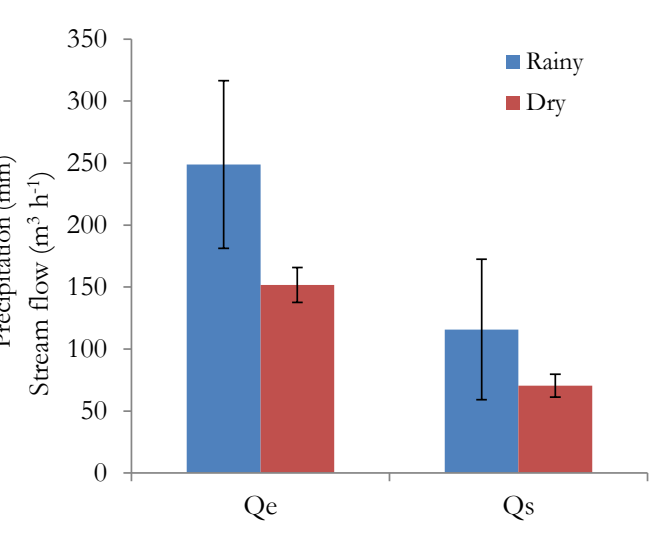

FIGURE 8. Temporal variation of the rainfall during the 7 days before the assessments (P7d) and of the input $(\mathrm{Qe})$ and output flow $(\mathrm{Qs})(\mathrm{a})$ and averages of Qe and Qs in the rainy and dry periods (b).

Regarding the magnitude of average water availability in the basin, considering the specific average stream flow observed from $32.05 \pm 3.97 \mathrm{~m}^{3} \mathrm{~km}^{-2} \mathrm{~h}^{-1}$, it was found that it is above of the average in its river basin, the sub-basin Água Vermelha/Pádua Diniz, which is of $26.05 \mathrm{~m}^{3} \mathrm{~km}^{-2} \mathrm{~h}^{-}$.

\section{Total Solid Discharge}

The total solid discharge (DST) range from 941 to $28,500 \mathrm{~kg} \mathrm{~d}^{-1}$ at the input (DST $_{\mathrm{e}}$ ) and 130 to $789 \mathrm{~kg} \mathrm{~d}^{-1}$ at the output (DSTs), both showing high positive correlation ( $\mathrm{r}=0.71$ to the input and $\mathrm{r}=0.62$ to the output) with the P7d (Figure $9 \mathrm{a}$ ).

It was observed that regardless of the season (rainy or dry) or the estimated location (input and output of the dam), there were significant differences between means. Observed means DSTe and DSTs were $12.257 \pm 8.191$ and $0.716 \pm 0.038 \mathrm{t} \mathrm{d}^{-1}$ in the rainy period and $1.634 \pm 0.258$ and 
$0.311 \pm 0.059 \mathrm{t} \mathrm{d}^{-1}$ in the dry period (Figure $9 \mathrm{~b}$ ) and average specific production periods of $0.781 \pm$ $0.407 \mathrm{t} \mathrm{km}^{-2} \mathrm{~d}^{-1}\left(285 \pm 149 \mathrm{t} \mathrm{km}^{-2} \mathrm{yr}^{-1}\right)$.
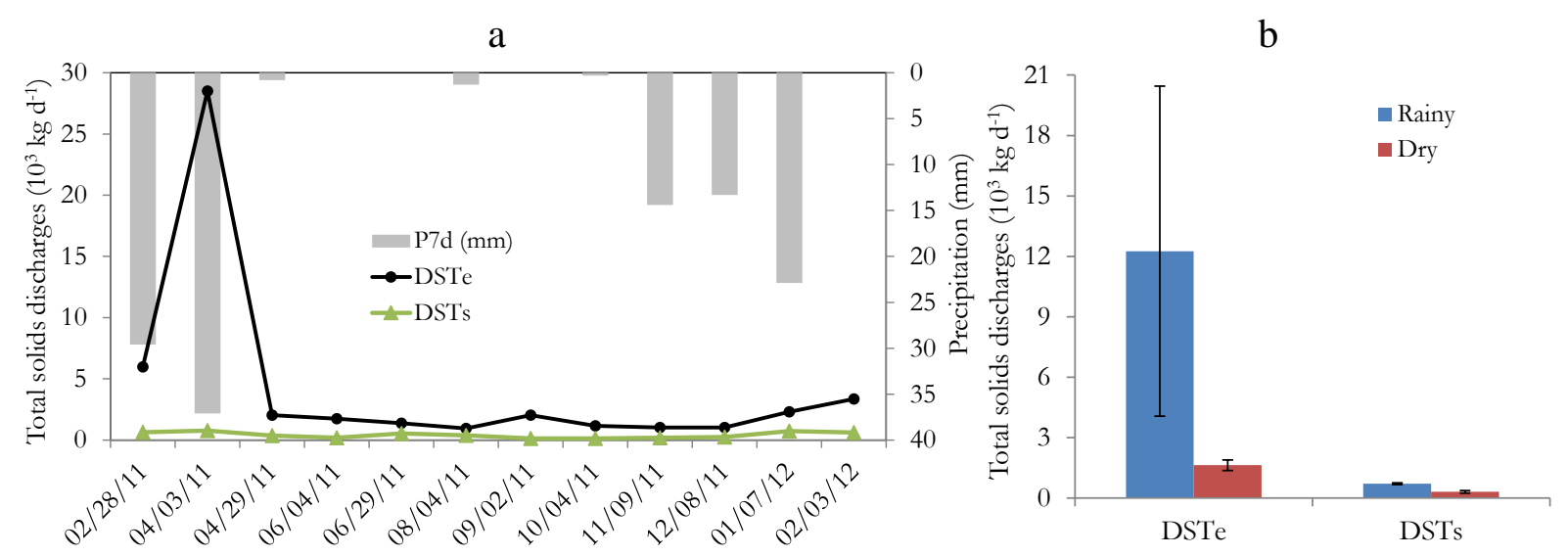

FIGURE 9. Temporal variation of the rainfall during the 7 days before the assessments (P7d) and of the input (DSTe) and output of total solid discharges (DSTs) (a) and averages of DSTe and DSTs in the rainy and dry periods (b).

According to the classification proposed by CARVALHO et al. (2000), the specific sediment production on the basin has a high potential for siltation of the Fernandópolis dam, which explains its reduction on the water mirror of $48.3 \%$ between the years 1979-2008 (VANZELA, 2012 ).

Among the observed factors that contribute to this high sediment yield, can be highlight the degradation of forests, agricultural activities and urban expansion. As noted, only $7.5 \%$ of the drainage area of the basin (Figure 2) still has preserved native vegetation, but mostly located outside of areas of permanent preservation. This fact associated with the situation of not conserved grazing (38.2\% of the basin) and urban sprawl (43.8\% of the basin) without the control of slopes, can be considered the main factors acting in excessive production of sediment on the dam.

\section{Siltation}

In the present condition, the results show a significant mean of sediment mass retention on the dam in the rainy season $\left(11.542 \pm 8.167 \mathrm{t} \mathrm{d}^{-1}\right)$ to dry season $\left(1.322 \pm 0.235 \mathrm{t} \mathrm{d}^{-1}\right)$, which correspond to a variation of 53.9 to $94.5 \%$ in sediments retention (Figure 10).

a

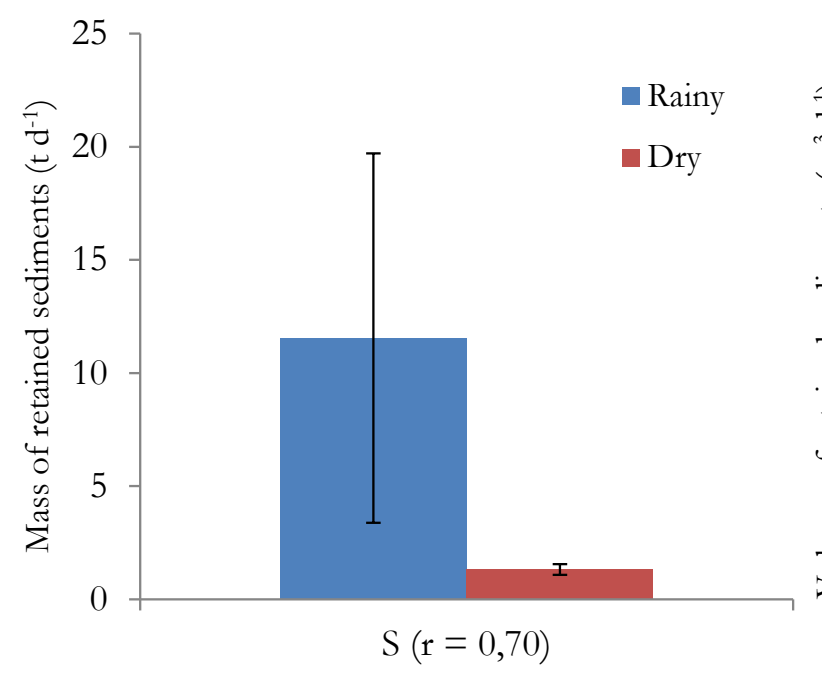

b

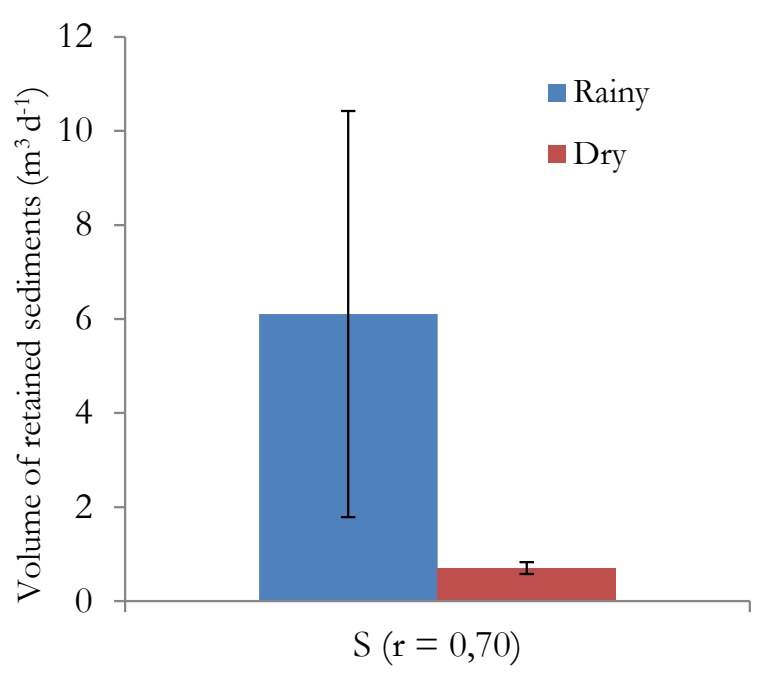

FIGURE 10. Mass (a) and volume (b) of sediments retained in the dam during the rainy and dry periods. 
Variations in retention capacity estimated in sediment on dams were $66 \%$ on average for some Brazilian basins (SOUZA FILHO, 2013). In China, HU et al. (2009) estimated for Three Gorges dam an efficiency in retaining sediment on the order of $75 \%$. Volume retention average in rainy and dry period was respectively, $6.11 \pm 4.32$ and $0.70 \pm 0.12 \mathrm{~m}^{3} \mathrm{~d}^{-1}$.

Considering the current measured volume of the dam $\left(18,598 \mathrm{~m}^{3}\right)$ and the average annual volume of sediment retained in the dam $\left(729 \pm 425 \mathrm{~m}^{3} \mathrm{yr}^{-1}\right)$, if no corrective-preventive measure is adopted, it is expected that the complete sedimentation of Fernandópolis municipal dam occurs in at most in 57 years, according to the standard mean error.

In view of that the dam is strategically located to capture water for irrigation $(38.2 \%$ of the area consists of grassland), boosting the local economy, it is recommended that preventive measures are taken to minimize sediment production levels consistent with tolerable natural production, and corrective, aiming to restore the useful original volume and capacity of water storage.

Preventive measures should include reducing the overland flow basin through forest restoration in the areas of permanent preservation, techniques of crop rotation, contour planting, terracing, gully recovery (STEPHENS, 2010) and master plans with rational urban sprawl. As a corrective measure, knowing that the water mirror silted in 1979 compared to the current was approximately $17,500 \mathrm{~m}^{2}$ (VANZELA, 2012) and the current average depth of about $1.0 \mathrm{~m}$, it is recommended the withdrawal of at least $17,500 \mathrm{~m}^{3}$ of sediment by dredging.

\section{CONCLUSION}

The percentage of sediment retention on the dam in the city of Fernandópolis ranged from 53.9 to $94.5 \%$, that associated with a high specific sediment production causes its full silting in at most 57 years. To avoid this process it is recommended that preventive measures such as the restoration of permanent preservation areas and corrective measures such as the removal of 17,500 $\mathrm{m}^{3}$ sediment of the dam.

\section{REFERENCES}

ALBERTIN, L. L.; MATOS, A. J. S; MAUAD, F. F. Cálculo do volume e análise da deposição de sedimentos do reservatório de Três Irmãos. Revista Brasileira de Recursos Hídricos, Porto Alegre, v. 15, n. 4 , p. $57-67,2010$.

CARVALHO, N. O. Hidrossedimentologia prática. $2^{\mathrm{a}}$ ed. rev. atual. e ampl. Rio de Janeiro: Interciência, 2008. 600p.

CARVALHO, N. O.; FILIZOLA JÚNIOR, N. P.; SANTOS, P. M. C.; LIMA, J. E. F. W. Guia de avaliação de assoreamento de reservatórios. Brasília: ANEEL, 2000. 107p.

CENTRO INTEGRADO DE INFORMAÇÕES AGROMETEOROLÓGICAS. Dados climáticos da estação agrometeorológica de Fernandópolis - SP. Disponível em:

<http://www.ciiagro.sp.gov.br/ciiagroonline>. Acesso em: 20 mar. 2012.

DOORENBOS, J.; KASSAN, A.H. Yeld response to water. Rome: FAO, 1983. 193 p. (Irrigation and Drainage Paper, 33).

GOMES, N. M.; FARIA, M. A. DE; SILVA, A. M. DA; MELLO, C. R. DE; VIOLA, M. R. Variabilidade espacial de atributos físicos do solo associados ao uso e ocupação da paisagem.

Revista Brasileira de Engenharia Agrícola e Ambiental, Campina Grande, v.11, n.4, p.427-435, 2007.

GRAVETTER, F. J.; WALLNAU, L. B. Statistics for the behavioral sciences. $2^{\text {nd }}$.ed. St. Paul: West Publishing, 1995. 429p.

HOPKINS, W. G. A new view of statistics. Internet Society for Sport Science. Disponível em: http://www.sportsci.org/resource/stats/. Acesso em: 23 jan. 2008. 
HU, B.; YANG, Z.; WANG, H.; SUN, X.; BI, N.; LI, G. Sedimentation in the Three Gorges Dam and the future trend of Changjiang (Yangtze River) sediment flux to the sea. Hydrology and Earth System Sciences, Goettingen, v.13, p.2253-2264, 2009.

LU, X. X.; SIEW, R. Y. Water discharge and sediment flux changes over the past decades in the Lower Mekong River: possible impacts of the Chinese dams. Hydrology and Earth System Sciences, Goettingen, v.10, p.181-195, 2006.

MEDEIROS, P. R. P.; KNOPPERS, B.; SOUZA, W. F. L.; OLIVEIRA, E. N. Aporte de material em suspensão no baixo rio SÃO FRANCISCO (SE/AL), em diferentes condições hidrológicas. Brazilian Journal of Aquatic Science and Technology, Itajai, v.5, n.1, p.42-53, 2011.

MELO, C. de A.; MOREIRA, A. B.; BISINOTI, M. C. Perfil espacial e temporal de poluentes nas águas da represa municipal de São José do Rio Preto, São Paulo, Brasil. Química Nova, São Paulo, v.32, n.6, p.1436-1441, 2009.

MINGOTI, R.; VETTORAZZI, C. A. Relative reduction in annual soil loss in micro watersheds due to the relief and forest cover. Revista Brasileira de Engenharia Agrícola, Jaboticabal, v.31, n.6, p.1202-1211, 2011.

OLIVEIRA, J. B.; CAMARGO, M. N.; ROSSI, M.; CALDERANO FILHO, B. Mapa pedológico do Estado de São Paulo: legenda expandida. Campinas: Instituto Agronômico/EMBRAPA Solos, 1999. 64p.

OLIVEIRA, L. C. de; PEREIRA, R.; VIEIRA, J. R. G. Análise da degradação ambiental da mata ciliar em um trecho do Rio Maxaranguape-RN: uma contribuição à gestão dos recursos hídricos do Rio Grande do Norte - Brasil. Holos Environment, Rio Claro, v.5, p.49-66, 2011.

PEREIRA, A. R.; ANGELOCCI, L. R.; SENTELHAS, P. C. Agrometeorologia: fundamentos e aplicações práticas. Guaíba: Agropecuária, 2002. 478p.

POLETO, C.; CARVALHO, S. L. de; MATSUMOTO, T. Avaliação da qualidade da água de uma microbacia hidrográfica no município de Ilha Solteira (SP). Holos Environment, Rio Claro, v.10, p.95-110, 2010.

ROLIM, G. de S.; CAMARGO, M. B. P. DE; LANIA, D. G.; MORAES, J. F. L. de. Classificação climática de Köppen e de Thornthwaite e sua aplicabilidade na determinação de zonas agroclimáticas para o Estado de São Paulo. Bragantia, Campinas, v.66, p.711-720, 2007.

SANTANA, J. A. V.; COELHO, E. F.; FARIA, M. A.; SILVA, E. L.; DONATO, S. L. R . Distribuição de raízes de bananeira prata-anã no segundo ciclo de produção sob três sistemas de irrigação. Revista Brasileira de Fruticultura, Jaboticabal, v. 34, p. 124-133, 2012.

SANTOS, G. O.; HERNANDEZ, F. B. T. Uso do solo e monitoramento dos recursos hídricos no córrego do Ipê, Ilha Solteira, SP. Revista Brasileira de Engenharia Agrícola e Ambiental, Campina Grande, v.17, n.1, p.60-68, 2013.

SILVA, A. E. P.; ANGELIS, C. F.; MACHADO, L. A. T.; WAICHAMAN, A. V. Influência da precipitação na qualidade da água do Rio Purus. Acta Amazonica, Manaus, v.38, n.4, p. 733-742, 2008.

SILVA JUNIOR, V. P.; MONTENEGRO, A. A. A.; SILVA, T. P. N.; GUERRA, S. M. S.; SANTOS, E. S.; Produção de água e sedimentos em bacia representativa do semiárido pernambucano. Revista Brasileira de Engenharia Agrícola e Ambiental, Campina Grande, v.15, n.10, p.1073-1081, 2011.

SOUZA FILHO, E. E. As barragens na bacia do rio Paraguai e a possível influência sobre a descarga fluvial e o transporte de sedimentos. Boletim de Geografia, Maringá, v.31, n.1, p.117-133, 2013. 
STEPHENS, T. Manual on small earth dams: a guide to siting, design and construction. Rome: FAO Irrigation and Drainage, 2010. 114p. (Paper 64).

SYVITSKI, J. P. M.; KETTNER, A. Sediment flux and the Anthropocene. Philosophical Transactions of The Royal Society A, London, v.369, p.957-955, 2011.

VANZELA, L. S. Evolução da paisagem do município de Fernandópolis - SP. In: PREFEITURA DE FERNANDÓPOLIS (Org.). Fernandópolis nossa história, nossa gente. São Paulo: Anglo, 2012. v.2, p. 246-266.

VANZELA, L. S.; HERNANDEZ, F. B. T. H.; FRANCO, R. A. M. Influência do uso e ocupação do solo nos recursos hídricos do Córrego Três Barras, Marinópolis. Revista Brasileira de Engenharia Agrícola e Ambiental, Campina Grande, v.14, n.1, p.55-64, 2010.

TUNDISI, J. D.; TUNDISI, T. M. Impactos potenciais das alterações do Código Florestal nos recursos hídricos. Biota Neotropica, Campinas, v.10, n.4, p.67-75, 2010.

UNITED NATIONS ENVIRONMENTAL PROGRAMME. Dams and development: relevant practices for improved decision-making. Nairobi: UNEP, 2007. 176p.

WU, C. S.; YANG, S. L.; LEI, Y. Quantifying the anthropogenic and climatic impacts on water discharge and sediment load in the Pearl River (Zhujiang), China (1954-2009). Journal of Hydrology, Amsterdam, v.452-453, p.190-204, 2012. 